\title{
1 Methodological nationalism and migration studies
}

\section{Historical and contemporary perspectives}

\author{
Pedro T. Magalhães and Laura Sumari
}

\section{Introduction}

Social scientists struggle when they confront the phenomenon of nationalism. Their predicament is understandable, for, on closer inspection, nationalism is fraught with paradoxes. Their temptation to discard the topic altogether, and their refusal to engage with it on a deeper level even for critical purposes, might therefore appear justified. However, such a temptation must be resisted. In particular, migration studies and refugee scholarship have the duty to resist it, for their heuristic and critical potential hinges to a large extent on the capacity to question the national frameworks and nationalist assumptions, which, whether consciously or less so, still predominantly inform migration and refugee policies. This chapter approaches the issue of methodological nationalism in the social sciences from both a historical and a contemporary perspective. First, it delves into its early intellectual history by examining Eric Voegelin's reflections on 'national minds' in the interwar period. Thereafter, we examine the persistence of nation-state-centred concepts and methods in the context of migration and refugee studies, and we discuss different conceptual tools for overcoming the insufficiencies of methodological nationalism, weighing both their fruitfulness and their limits, while not ignoring the ineradicability of such frameworks.

Scholars of nationalism point out that, among other aporias, nationalist thinking combines a lack of substance and elaboration on the ideational level with unmatched effectiveness when it comes to mobilising people to take political action. Despite its 'philosophical poverty', ${ }^{1}$ nationalism seemingly has a grip on mass popular feeling like no other modern ideology. ${ }^{2}$ To be sure, it is debatable whether this combination is, in fact, paradoxical. Indeed, one does not need to endorse a dismal view of the masses and crowds to accept that theoretical sophistication might be a hindrance to the political 'power' of ideas. The importance of intellectual brokers who can mediate between 'grand thinkers' and street-level activists has long been stressed in the cases of the purportedly more elaborate ideologies of socialism and liberalism. ${ }^{3}$ The phenomenon of methodological nationalism, on the other hand, is much more puzzling, for it pertains to the impact of such a seemingly unsophisticated ideology on the ways in which scientists, and especially social scientists, have 
framed research problems, developed analytic tools and presented their findings and conclusions. This chapter sheds some light on this predicament.

Methodological nationalism is more elusive a phenomenon than ideological nationalism. It works mostly by way of unexamined assumptions and omissions. Still, it would be absurd to argue that the two are unrelated. In fact, it is the political success of nation and state-building processes in the modern age, fuelled by nationalist ideologies, which ultimately explains the persistence of methodological nationalism in the social sciences, for modern social science emerged and consolidated within the expanding national structures of higher education and scientific research. In an analysis of nationalism as a political ideology, Michael Freeden notes that the nationalist universe of meaning revolves chiefly around the core principle that the nation constitutes the irreplaceable framework for identity and culture. This principle generates an object of reverence that ranks above all other individual or collective subjectivities and nurtures the nationalist desire, framed as an inalienable right, to consolidate the supposedly primordial cultural unit of the nation as a sovereign political unit. Territorial contiguity and historical continuity, real or imagined, as well as an emphasis on affect and emotion that has no parallel in other modern ideologies, are the resources nationalists draw upon to foster sentiments of belonging and solidarity. ${ }^{4}$

Nationalism has crept into the social sciences not in its overt ideological forms - or, at any rate, not only in such forms - but rather by their taking for granted, as given and natural, the nationalist image of the world. Just as it trickles down to ordinary language and everyday practice until it becomes virtually unrecognisable as such, ${ }^{5}$ nationalism exerts a powerful influence on the human and social sciences by furtively suggesting that the lines separating nation-states from each other on political maps coincide with those that single out the meaningful units for social scientific inquiry. Wimmer and Glick Schiller ${ }^{6}$ identify three analytically distinct, but in practice overlapping, modes of methodological nationalism: ignorance, naturalisation and territorial limitation. Ignoring the national framework of modernity is a characteristic feature of social theory, with its grand narratives of epoch-making transitions from traditional, pre-modern communities to modern society. If the changes brought about by capitalism - a global and transnational phenomenon if there ever was one - constitute the focal point of modern social theory, nationalism is arguably its blind spot. In other words, social theory has failed to problematise the perplexing fact that the transition to an allegedly homogeneous type of capitalist/industrial society has proceeded hand in hand with the creation and strengthening of discrete national political communities. This lack of theoretical engagement leads, at the level of empirical research, to the naturalisation of the principle that the nation, or society understood as strictly contained within nation-state boundaries, constitutes the most suitable framework for social scientific analysis. Such naturalisation, ultimately, limits the territorial imaginary of the social sciences and removes from sight, with the help of statistical data collected by - and for the specific purposes of - nation-states, the porosity of national borders. 
The bias that accrues from such silent background assumptions is as difficult to expose as it is to avoid. Although efforts at dodging and debunking methodological nationalism are in general commendable - especially in the study of such topics as migration, which has been particularly affected by it - it would be a naïve presumption to expect that they could help us attain an 'objective' understanding of social reality. What stands to be gained from overcoming the alluring self-evidence of a world divided into discrete nationstate containers is not the world as it really is, but merely another, possibly novel yet also irremediably incomplete, perspective on it. Above all, the challenge of methodological nationalism should make us aware of how inescapably the theoretical language we, as scholars, use to make sense of the world is shaped by the intellectual, social and political forces around us, thus precluding the possibility of a clear-cut distinction between scholarship and politics, science and ideology.

Thus, in this chapter we focus on the plurality of approaches that follow from problematising the silent assumptions of methodological nationalism. Refusing to ignore the national framework of modernity and/or to naturalise the nation-state as a unit of analysis is always only a first step, one which can lead in different directions depending on the intellectual and political forces that drive it. Awareness of the analytical limitations imposed by nationalist frameworks can translate into several emphases: an emphasis on the processes and fluxes that cut across nation-state borders and therefore call for a macroscopic approach; an emphasis on the rediscovery of the internal diversity that nation and state-building processes sought to erase through various policies of homogenisation; or an emphasis on the persistent ideological and political strength of nationalism. In the final analysis, each encounter with the problems of methodological nationalism generates a story of its own, which is intertwined with the histories both of nationalism proper, as a movement and as an ideology, and of the social scientific discourses informing it. To illustrate this point, we begin with a contribution to the intellectual history of methodological nationalism.

\section{Struggling with methodological nationalism avant la lettre: Eric Voegelin and the 'national types of mind' (1920-1930)}

From an historical perspective, the concept of methodological nationalism is a recent artefact. The term was coined by the sociologist Hermínio Martins in the 1970s, but it played only a peripheral role in his dense plea for a historically and philosophically reflexive sociology. The coinage of the expression seems to be almost accidental, as the concept does not in fact occupy a prominent place in Martins's reflections. However, its emergence can be read as signalling an awakening to the entrenchment of nationalist assumptions in social-scientific methodology after the Second World War. In the brief passage where he comes up with the term to refer to the shortcomings of contemporary macro-sociological studies, Martins ${ }^{7}$ points out that scholars succumb unreflectively, and irrespective of nationalist political leanings, to 
'national pre-definitions of social realities'. What is more, he notes that migration studies in particular reveal the inadequacy of such 'pre-definitions', with their focus on immigration and integration in the host society resulting not from valid scientific reasons, but rather from the institutional embeddedness of the social sciences in rich, immigrant-receiving societies. ${ }^{8}$

Roughly one decade later, in an article that took stock of classical social theory's neglect of nationalism, Anthony D. Smith related the pervasiveness of methodological nationalism to 'the difficulty for a discipline so impregnated with the selfsame assumptions as those held by its object of study, to stand back and realize its historical peculiarity'. ${ }^{9}$ But Smith, much like the other renowned scholars who accompanied him in a new wave of nationalism studies that peaked in the $1980 \mathrm{~s},{ }^{10}$ was only marginally interested in methodological issues. The research problems pertaining to the origins, diffusion and consequences of the phenomenon had too strong a grip on these scholars of nationalism to allow for anything more than a secondary concern with the unexamined adoption of national(ist) analytic frameworks by the mainstream social sciences. ${ }^{11}$ Ultimately, only when the limitations of such frameworks became more glaring as a result of growing global interdependencies did a systematic critical treatment of methodological nationalism, as well as an epistemic move away from it, become possible - and it comes as no surprise that this was achieved, first and foremost, by migration scholars. ${ }^{12}$

However, it would be overly simplistic to reduce the story of metatheoretical reflections on the methodological implications of nationalism to a linear account departing from a position of ignorance and short-sightedness, during the heydays of classical social theory and nation-state-building processes, and culminating in a systematic critique motivated by the rise of a new, post-national constellation. In this section, we sketch the early trajectory of a scholar who began his academic career in interwar Vienna, struggling with methodological nationalism before the term had been invented. Although his struggle was not successful in the sense of leading to a systematic comprehension of the phenomenon, it is worth recovering here for two main reasons. On the one hand, Eric Voegelin's case provides some nuance to the charges of neglect and ignorance of nationalism levelled against classical social theory. On the other hand, it reveals some deep tensions and dilemmas crisscrossing scholarship and politics at the time, which arose from an early, though neither complete nor fully articulate, grasp of the repercussions of nationalism on social scientific research.

Voegelin completed a doctorate at the University of Vienna in 1922, with his thesis on the epistemological foundations of sociology in essence being a defence of Othmar Spann's idea of spiritual community (Gezweiung), in contrast to Georg Simmel's concept of interaction (Wechselwirkung), as the soundest methodological basis for sociological investigations. ${ }^{13}$ However, much more interesting than the theoretical arguments per se, are the sparse yet revealing references to the concrete problems that sociological research was supposed to address. For instance, when Voegelin specifies the claim that sociology should 'grasp the phenomenon [it studies] in its social nature', he adds that it 'must be able to tell us why a particular painting is a Dutch 
painting, why a particular philosophical system is French, etc..${ }^{14}$ By doing so, far from conflating the categories of society and nation, Voegelin is rather suggesting that national definitions of social entities, no matter how natural and intuitive they might appear, require further sociological elucidation. Instead of taking national labels for granted, sociologists must be able to explain why it makes sense to use them, why certain national labels capture the 'social nature' of a phenomenon better than other alternatives.

Voegelin is well aware of the fact that membership in a society need not be understood in national terms, but at the same time he is fascinated by the pervasiveness of the national colourings assigned to social and cultural objects, which occur even in the most improbable connections. In this regard, he mentions Pierre Duhem's study La théorie physique as a remarkable example of how to employ the sociological method as he understood it. To be sure, this is a bit of an overstatement, since Duhem was only somewhat interested in the 'social nature' of theoretical physics. However, the contrast that Duhem drew between the abstract penchants of French (and German) physicists, on the one hand, and the tendency of their English counterparts to construct sensorially graspable models on the other hand, impressed Voegelin deeply. ${ }^{15}$ Even at such a point where the human mind strives for the highest degrees of abstraction and objectivity in the elucidation of natural phenomena, it apparently does so through different, socially/nationally determined routes.

If not even theoretical physics could efface the traces of national provenance, then the social sciences were bound to reveal them much more starkly. But how starkly would they reveal such traces, and how would it affect their claims to scientific validity? Voegelin wrestled with this question in his 1922 essay on 'The Social Determination of Sociological Knowledge'. In it, he evaluates contemporary British sociology, and precisely by discerning just what makes it British, Voegelin hopes to define the concept of a nation in the hope of better ascertaining its epistemological implications. Since 'a national element is a necessary concomitant in the determination of knowledge', no science, hard or soft, could aspire to produce only judgments scrupulously valid to 'consciousness generally', in a Kantian-transcendental sense. However, he proceeds, this must not lead one to abandon 'the possibility of an objective science as well as of an objective critique'. After all, Duhem ${ }^{16}$ had shown that the two nationally distinct modes of theorising could still contribute to the consolidation of a unified theory of physics. Voegelin's suggestion, thus, is that one should conceive of the 'system of knowledge' as a two-fold structure. On one plane, which he deems 'objective', scientific progress unfolds in the form of judgements that meet the requirements of validity for 'consciousness generally'. These judgements, however, emerge from another, 'subjective' plane that is inescapably marked by its social/national provenance. ${ }^{17}$

The problem with this dualistic construct is, however, that its own conception of the locus of 'true' scientific progress stems from a particular national perspective, one which is therefore presumed to have privileged access to the transcendental realm of objectivity. This leads Voegelin to the following, weirdly nationalist conclusion: 
In order to produce useful findings relevant to the type of transcendental sociology we have outlined here, sociologists, in terms of their mental structure, would have to be transcendental philosophers - and whether we can find this type of philosopher outside of Germany seems highly questionable. $^{18}$

During the 1920s, two factors would help Voegelin see past this strict neoKantian framework: lengthy research visits to the United States and France and his immersion in Max Weber's sociological work. Although both are relevant for a complete account of the development of his conception of 'national types of mind', we will focus here only on the latter. Weber is arguably the member of the classical sociological canon who can least be charged with being blind to the role of nationalism in the making of the modern world. To be sure, his actual contributions to the topic are brief and fragmentary, but the reason for this is hardly the kinds of unexamined omissions and ignorance that present-day critics of methodological nationalism detect in mainstream social theory. ${ }^{19}$ The rather more prosaic explanation is that Weber did not live to complete his political sociology, where he intended to give an account of the rise of the modern nation-state. Still, the six-page fragment published posthumously in Economy and Society contains important clues that later students of nationalism - often without any discernible Weberian influence - would pursue.

Weber's analytic move sought to disentangle the compound 'nation-state' and reflect on the nature of each of its components. While 'the state' is, above all, a rational construct, one graspable via a precise definition ${ }^{20}$ and amenable to the ideal of value-free inquiry that modern social science aspires to, "the nation' resists clear-cut definition and confronts scholars head-on with an irrational sphere of ultimate values and commitments. Furthermore, the difficulties are sharpened by the fact that scholars belong precisely to the social group that is most attached, by way of both material and ideal interests, to the valueladen complex of 'the nation'. Indeed, whereas the idea of 'the state' is carried forward by the political elites, the 'national' ideal is advocated primarily by the intellectual strata of modern societies. Paradoxically, those very same scholars who, because of their scientific vocation, should study 'the nation' as objectively as possible, i.e. from an axiologically neutral perspective, are at one and the same time those who, due to their social position among the intelligentsia, 'are specifically predestined to propagate the "national" idea'. ${ }^{21}$ Being a German nationalist himself, Weber was well aware of the weight of such a paradox.

Voegelin, too, proceeded to elaborate on the social/national determination of social scientific minds in the spirit of the scholar he viewed as the 'mightiest symbol' of his time. ${ }^{22}$ In December 1930, he delivered a lecture-series entitled 'National types of mind, and the limits to interstate relations' at the recently established Institut Universitaire de Hautes Études Internationales, in Geneva. Unsurprisingly, the lectures generated no enthusiasm in the capital city of interwar internationalism. The directors of the Institut, who had considered offering Voegelin a position based on an endorsement by his mentor 
Hans Kelsen, eventually decided against it. Indeed, sentences such as the following were hardly a good calling card in the same city that hosted the League of Nations:

A sociologist who has even only a superficial knowledge of the sociological literature outside his own nation may find his attention attracted to the interesting circumstance that another nation's results in sociological theory are of negligible value for his own work when he takes them as objective science. There is no Internationale of social theory as there is of mathematical or physical theory. ${ }^{23}$

Considering the evolution of Voegelin's intellectual trajectory, the above summation signals a clear break with the neo-Kantian influence exerted by Kelsen. In other words, while neo-Kantian epistemology might be adequate for our understanding of the natural sciences in general and Newtonian physics in particular, it is irrelevant for the social sciences - and for all the social sciences at that - because meaningful social phenomena cannot be subsumed under a unified theory of experience. But if social phenomena must be grasped, so to speak, from within, by someone who is implicated in such phenomena, then the tense situation that Weber noted concerning the study of 'the nation' is indeed unavoidable. Voegelin's answer differs, however, from that of Weber. For Weber, the crux of the matter was choosing which 'God' to serve, which fundamental calling to pursue: science or politics? For Voegelin, the paradox, being more than a matter of choosing between two supposedly incompatible alternatives, called for rigorous self-reflection. Torn between irreconcilable demands, the scholar must 'be the perfect master of his thought and ... know in all clarity what parts of his thought may be regarded as rational, and where the irrational belief comes in'. ${ }^{24}$ To be the servant of rational science, and rational science only, was not an option, because according to his 'existential conception ... there is not a realm of politics an sich, and beyond it the sphere of science, but political science itself is a part of political existence'. ${ }^{25}$ The mark of a scholar's intellectual integrity, and of his/her political responsibility, was the ability to distinguish thoughtfully between the elements of rational-scientific truth and those of irrational national belief that necessarily inform one's work. Conflating the latter with the former, taking belief for unbiased truth, was the first step in the sacralisation of one's own national beliefs and the incomprehension of other nations' beliefs. The scholars who are able to maintain such a distinction are not quite the type of socially unattached intellectual in whom Karl Mannheim ${ }^{26}$ had placed his hopes of social reconstruction in an important contemporary work, precisely because their national attachments are ineffaceable, but they might still contribute to further the understanding between nations by 'having a clear picture of each other's peculiar beliefs' ${ }^{27}$

Whether Voegelin was able to live up to this demanding image of the nationally self-reflecting scholar in the years leading up to the Anschluss of Austria by the Nazis is somewhat doubtful given his legitimation of the 
nation and state-building policies of Austrofascism. ${ }^{28}$ Still, his struggle during the 1920s with the problem of 'national minds' and their influence on knowledge production can be interpreted as an early, tentative venture into the topical issues of methodological nationalism. Voegelin proceeded from epistemology to concerns that are more political. At first, still clinging to the possibility of achieving objective knowledge, he nevertheless recognised and tried to come to terms with the fact that every scientific theory is marked by its peculiar national provenance. Subsequently, in acknowledging the sheer force of nationalism as a political belief he was expressing the understanding that the social and political sciences cannot hope to remain insulated from it, but rather should aim to distinguish as clearly as possible between their rationally unjustifiable, nationalist commitments and their rational-scientific achievements. To be sure, Voegelin did not fully grasp what we today see as the problems of methodological nationalism, and much less did he arrive at a systematic critique of the phenomenon. Often enough, he took nationalist assumptions for granted - unsurprisingly, perhaps, for someone who was witnessing, with a sense of anxiety, the partition of the Habsburg Empire into discrete nation-states - but he certainly did not ignore the national framework of modernity and the perplexing questions generated by it. Later on, while in exile in the United States, he would treat nationalism as one of the ominous political religions of the modern age, an age he sweepingly condemned as one of spiritual corruption and 'theoretical retrogression'. ${ }^{29}$ However, such a critique of philosophical rather than social scientific interest falls beyond the scope of the present inquiry.

\section{Methodological nationalism in contemporary research on migration}

The national frame of modernity is particularly visible in migration management and in the development of migration and refugee studies shaped by the modern projects of nation-state building. ${ }^{30}$ Not only is the history of migration written largely from the viewpoint of nation-states, it is also most often written using concepts related to nation-states. ${ }^{31}$ Although the increased interest in migration and refugee studies related to the so-called 'refugee crisis' has given birth to productive debates on post-nationalism as well as denational and transnational citizenship that recognise the nation-state as merely one of the multiple layers of political membership, ${ }^{32}$ migrants are still often seen primarily as 'representatives' of their country of origin and/or of their nationality. This is visible in, for example, the sampling schemes of national surveys and statistics representing migration, which focus on the nationality of migrants as well as the crossing of borders, thus naturalising the roles of states. Equally, migration is often studied from the point of view of the recipient country since the recipient country is responsible for the asylum determination process as well as providing services to migrants. Immigration is, by definition, studied in relation to the nation-state receiving the migrant, who is entering the country from the 'outside'. ${ }^{33}$ This kind of research has focused strongly on integration, which has been seen as the 
'natural' terminal point to the migratory process. ${ }^{34}$ Just as nation-state institutions presumably provide the most relevant social context for understanding and studying migration, so too many researchers continue to assume that nation-states provide the most appropriate territorial framework for migration research. ${ }^{35}$

One reason that adhering to nation-state-related social and territorial frames in refugee and migration research may feel natural for researchers is that as determinants of juridical, social and cultural citizenship, nation-states are the bodies largely responsible for managing and organising migrationrelated issues. Migration processes and immigration law are heavily shaped by racialised conceptions of citizenship and national identity. Yet, it must be noted that national categories are not the sole markers of exclusion: racialised or ethnicised 'others', such as Blacks, Muslims or Roma, may well be citizens, but they become 'migrantised' by the nation-state. In addition to national borders, the boundaries of entitlement and disentitlement also relate to transnational capitalism - border regimes work especially to control the mobility of the poor. ${ }^{36}$ Various forms of exclusion are, thus, interlinked and inform each other.

The uncritical assumption of 'national' analytical frameworks leads to the perception that state borders are lines that naturally divide the world. ${ }^{37}$ Additionally, by equating nation with 'peoplehood' and 'society' through the notions of democracy, citizenship, social security and national self-determination, ${ }^{38}$ methodological nationalism enforces the division between 'us' and 'them' on various levels. The legal-administrative categories that label migrants are related to the nation-state through the dichotomy of national and foreigner. They easily simplify and overlook the complex realities shaping the lives of migrants and create essentialist understandings of migratory movements, as Bergholm and Toivanen point out in this volume. Reducing the realities of migrants to push-and-pull factors and studying them through a national or ethnic lens does not necessarily reveal much about the real-life situations of the people who, for various reasons, are crossing borders and choosing to remain in a country other than the one of their birth..$^{39}$ Thinking beyond methodological nationalism thus requires a disarticulation of the binary between 'insiders' and 'outsiders' and the acknowledgement of multiple positionalities. ${ }^{40}$ This is easier said than done, as we have seen above. Despite acknowledging the need for self-reflection on one's national positioning as a scholar, Voegelin himself remained throughout the interwar years largely trapped within a nationally determined framework of thinking. But what kinds of analytical tools can we use that are not coloured by the 'selfevidence of a world ordered into nation-states'? ${ }^{41}$

Although national thinking often determines discussions about migration, ${ }^{42}$ there are multiple ways of attempting to avoid the traps related to methodological nationalism in contemporary migration and refugee studies. The starting point for this endeavour is to realise how strong the hold of the nation-state has been as a unit of inquiry in the social sciences. To move beyond the container-like understanding of nation-states, scholars have started to pay more 
attention to transnational relations. This has led to an emphasis on diverse mobilities (e.g. cross-national, regional, permanent, seasonal) and the transnational nature of phenomena that are in various ways hybrid and cross-border, where the relations between local and global are intertwined through various connections in space and time. ${ }^{43}$ As a consequence of shifting the analytical gaze away from the nation-state framework, increased attention has been paid to, for example, examining various cross-border social entities, modes of communality and transnational connections within and between migrant communities. ${ }^{44}$ The various approaches that critically examine methodological nationalism are the focus of the following section.

\section{Pathways towards de-naturalising the nation-state}

Anna Amelina and Thomas Faist ${ }^{45}$ write about various possibilities of moving beyond methodological nationalism in empirical research on migration. They propose methodological transnationalism as a way to 'de-naturalize the concept of the national within migration studies' by rejecting the nation-state as the only point of departure for empirical analysis. ${ }^{46}$ The starting point for a transnational approach is to pay attention to the various practices of people and institutions that take place in and across multiple localities. This can be done by, for instance, identifying alternative social and territorial frameworks for situating empirical research: transnational social spaces, postcolonial contexts or the global cosmopolitan arena.

De-centring the nation-state can also be done by focusing on strategies of space formation and space appropriation that understand spaces not as fixed and static entities (containers), but as relationally defined process-like things, which constantly gain new meanings and are constructed through various connections and networks. ${ }^{47}$ For instance, studying hybridities, diasporas and cosmopolitanism provides alternative paths to challenging national exclusivity and particularisms, and to analysing the ways in which people relate to multiple localities and organise transnational activities through them. ${ }^{48}$ However, the notions of diaspora and hybridity still rely on national imagery and potential mobilisations around national symbols. ${ }^{49} \mathrm{In}$ terms of gathering research material, the complexity of transnational phenomena can be gauged by studying multiple geographic localities and/or social sites simultaneously. Amelina and Faist ${ }^{50}$ have proposed using multi-sited ethnography ${ }^{51}$ and mobile methods as non-national ways of contextualising research to overcome some of the shortcomings of methodological nationalism.

The critique of methodological nationalism allows us to free our research from unjustified national frames. ${ }^{52}$ However, there is a risk of overcompensating and portraying the transnational in an excessively positive light..$^{53}$ Detaching hybridities and diasporic formations from the parameters of unequal power relations can downplay the negative effects of globalisation..$^{54}$ Although proponents of cosmopolitanism have claimed that the significance of borders and nation-states has diminished through the processes related to globalisation, ${ }^{55}$ it is important to bear in mind the persistent global inequalities 
related to the freedom of movement. Cosmopolitanism has been criticised for, among other things, overlooking questions of class as well as ethnic origin. ${ }^{56}$ Globalisation and the power geometries related to it have reserved different roles for different groups of people when it comes to movement. ${ }^{57}$ For instance, globalisation has not meant the fading away of borders for tens of millions of people stuck in refugee camps or otherwise unable to move. Rather, it has led to the multiplication of borders. ${ }^{58}$ According to Jussi Laine, ${ }^{59}$

we continue to live in the world of borders, and ... the state's allure has not faded, in spite of the fact that many contemporary social processes are clearly beyond its scope. Territorial logic still leaves its mark on the way space is organised, and the nation-state continues to be the principal reality for the worlds' inhabitants, 'trapped by the lottery of their birth'.

For this reason, when researching migration the relevance of states and borders in relation to various mobilities should neither be forgotten nor regarded as natural. This is true especially in the context of the increased securitisation of migration and the consequential amplifying of national borders and boundaries. ${ }^{60}$ Bridget Anderson ${ }^{61}$ proposes employing what she calls methodological de-nationalism as an approach that recognises the relevance of borders and nations by investigating the impacts of state-imposed categories of both migrant and citizen on the lived experiences of people, while seeking to uncover the connections between diverse but interconnected exclusionary logics. Indeed, methodological nationalism becomes an issue when it starts to direct our research in a way that is blind to other meaningful frames of inquiry. National identities remain salient building blocks of belonging and identification for many people around the world, and like researchers, migrants and refugees also experience themselves and their environments and connections with others in a world order that, to a certain extent, must still be conceptualised as consisting of nation-states. Yet nationality is not the only, nor always the strongest, marker of identity. Identity and belonging are concepts that inform understandings of migration in the modern era. Identities are slippery concepts - dependent on context, meaning and time which involve 'individual and collective narratives of self and other, presentation and labelling, myths of origin and myths of destiny with associated strategies and identifications' ${ }^{62}$ Thus, national belongings only account for a certain part of identity construction, which is a dynamic, thoroughly complex process involving multiple, overlapping layers, connections and dimensions.

People hold memberships and feel belonging through different categorisations, depending on the context, situation and meaning, and markers of identity are always intersecting and crosscutting each other. Shifting the focus from national fixation towards multiple positionalities and interlinked markers of identity (such as gender, class, region, political orientation and stage in the life cycle) that affect the subjectivity of individuals is one way of reaching beyond methodological nationalism. However, critiques of this kind of intersectionality warn that fixing people into inter-related, yet permanent groups, namely 
class, gender and ethnicity, undermines the focus on social processes and practices. Floya Anthias ${ }^{63}$ moves beyond intersectionality, proposing the notion of 'translocations', which 'references the idea of "location" as a social space which is produced within contextual, spatial, temporal and hierarchical relations around the "intersections" of social divisions and identities of class, ethnicity and gender (amongst others)'. The term refuses to see migrants solely based on their places of origin and destination; it includes other 'locations' of identity and belonging, such as gender and class. Additionally, and according to Anthias, when viewed separately from intersectionality the notion of translocations moves away from crosscutting groups and categories, emphasising social spatio-temporal processes and the role of boundaries and hierarchies.

When seeking to construct new epistemological frameworks for migration studies, we must understand how knowledge is produced and where it is situated. The basic claim of social constructivism is that reality is socially negotiated - the nature of truth is rhetorical. Knowledge is produced and reproduced in social interactions between human beings and their social settings. ${ }^{64}$ Instead of aiming for 'unmarked' objectivity, Donna Haraway ${ }^{65}$ proposes an 'embodied objectivity', which takes into account the situated nature of all knowledge. In speaking out against various forms of 'unlocatable, and so irresponsible, knowledge claims', she argues for 'politics and epistemologies of location, positioning, and situating, where partiality and not universality is the condition of being heard to make rational knowledge claims' ${ }^{66}$ For Haraway, feminist objectivity means positioned rationality - situated knowledges that are about communities, not isolated individuals:

Situated knowledges require that the object of knowledge be pictured as an actor and agent, not as a screen or a ground or a resource, never finally as slave to the master that closes off the dialectic in his unique agency and his authorship of 'objective' knowledge. ${ }^{67}$

Migration is a complex process, one which requires and generates a great deal of knowledge. Especially in the context of clandestine migration, plans and decisions have to be made and risks managed in rapidly-changing conditions and through new encounters between people. ${ }^{68}$ Studying migration provides an important opportunity to examine processes of knowledge production precisely because migrants are people who have moved out of their 'usual environment' and have to deal with many forms of the 'unknown' to survive in their everyday lives while in transit and in new locations. The geographically dispersed and fluid transnational milieu of migrants offers a ground for new 'communities of knowledge' where collective practices and complex processes of generating and using knowledge in irregular mobility facilitate the migratory journeys. ${ }^{69}$ Tekalign Ayalew Mengiste characterises 'communities of knowledge' through

the diverse and dynamic strategies collectively devised and mobilized by migrants, their co-travelers, families and friends settled en route and in the diaspora, and friendly strangers and diverse facilitators to reduce 
risks in clandestine journeys and who allow for successful transits, while not discounting the violence and suffering encountered by migrants and refugees on their paths. ${ }^{70}$

Mengiste $^{71}$ highlights how the relationships, information sharing and previous experiences related to migratory journeys reproduce social relations and construct knowledge, which is vital for decision-making throughout the migration process. Investigating the possible situatedness of migrant knowledges through a framework other than that of the nation-state requires further attention and raises further questions. Together with reflecting on the situatedness of migrant knowledges, de-naturalising nation-states in migration research requires careful consideration of the situatedness of academic knowledge production. Voegelin ${ }^{72}$ already long ago touched upon the responsibility of the researcher to distinguish between the elements of rationality and those of belief related to his subjectivity as a member of a nation. Accounting for the "nationally selfreflecting scholar' is connected to the positionality of the researcher. By positionality, we mean the space at the intersection of social position as a set of effectivities (structure) and social positioning as a set of practices (agency). ${ }^{73} \mathrm{We}$ have already discussed the multiplicity of positionalities in relation to the migrants who are the focus of the research. But researchers, too, occupy multiple positionalities, which affect our understanding of the world and the way we conduct research. Privileging the role of national belongings and ignoring our intellectual bias in relation to nation-states easily leads to overlooking the meanings of other social divisions in understanding migrant experiences. ${ }^{74}$ To critically engage with the presuppositions of methodological nationalism and the reconfigured role of the state in migration research, developing a self-reflexivity with respect to a variety of meaningful social divisions and understanding the significance of these multiple positionalities are crucial.

Academic representations are produced in asymmetrical power relations between the researcher and the researched. Especially in migration research, various sensitivities are related to such relations and overlooking them easily results in producing colonialist discourses on and knowledge about singular, essentialised identities. ${ }^{75}$ Since the backgrounds and power positions of the researcher and the researched often differ from each other in various ways, there is a danger of reproducing divisions between 'us' and 'them'. Equally, considering the relationship between the researcher and the researched through solely national belonging and identity leads to methodological nationalism. Kyoko Shinozaki ${ }^{76}$ argues that through social positioning, and by realising the non-static nature of the boundaries between 'us' and 'them', we can restructure the researcher-researched power relationship. Along with reflecting on one's position in society in terms of gender, class and ethnicity, this entails questioning fixed binary oppositions, for example those between insider and outsider - or the powerful and the powerless.

In migration studies, boundaries are easily drawn following the lines that separate nation-states. Yet these lines are only one of the many social divisions shaping the lives of migrants as well as those of the people studying 
migration. Equally, they are constantly being drawn and re-drawn through the social interactions between the researcher and the researched. Tapping into the field of migration studies and doing fieldwork with migrants requires constant and continuous self-reflexivity regarding multiple positionalities when assessing fieldwork relationships and the power (a)symmetries related to them..$^{77}$ Creatively assessing the intersecting but fluid, multiple positionalities of the researcher, the researched and the relationships between them offers necessary tools for questioning the naturalised role of the nation-state in social sciences and especially migration and refugee studies.

\section{Concluding remarks}

Total avoidance of methodological nationalism is a difficult, perhaps even an impossible task. Not only for researchers trying to understand complex social phenomena, such as migration, but also for all individuals and groups involved in such phenomena, nation-states are among the categories through which we understand ourselves and our identities in relation to the world we live in. Nationalism seems to be gaining a stronger hold in politics in many parts of the world, and populist anti-immigration parties are gaining in popularity through their simplistic discourses on migration and refugees. The significance of state borders for most of the world's population is not diminishing. It is important for migration scholars to understand the consequences of both ignoring and naturalising the role of the nation-state as well as of territorially limiting our research to the nation-state. Although globalisation influences the power geometries related to nation-states and the movements of people between them, we continue to live in a world where such territorial logic largely informs our understandings.

This chapter began with a historical overview of the problem of methodological nationalism in the social sciences. In the second section, we delved into the intellectual 'pre-history' of the concept by examining Eric Voegelin's interwar reflections on 'national minds', which, despite having been articulated long before the term was coined, anticipate many of the questions and challenges that future critics of methodological nationalism have tried - and are still trying - to solve. Next, we introduced some of the challenges related to the dominance of nation-state-centred frameworks of analysis within the context of migration and refugee studies. Finally, we discussed some of the conceptual and methodological tools for acknowledging and overcoming the potential traps of methodological nationalism.

At the end of the day, there is no one answer for avoiding the pitfalls of methodological nationalism, neither are we sure that it is entirely possible. Although many migrants also contextualise their existence and connections with others partially through the frame of the nation-state, the possibility for 'communities of knowledge' not marked by this framing can emerge from the connections and relationships forged in the migratory process. The current dynamics related to transnational migration present us with a multiplicity of shifting landscapes of identity and belonging, which can be approached through methodologies that 
consider the multiple positionalities of both migrants and the people who study migration as well as the relationships between them.

\section{Acknowledgments}

We would like to thank the editors and contributors to this volume for their helpful suggestions and insightful comments on previous drafts of this chapter. Furthermore, the authors also gratefully acknowledge the financial support of the Academy of Finland funded Centre of Excellence in Law, Identity and the European Narratives, funding decision numbers 312430, 336677, 312431 , and 336678 .

\section{Notes}

1 Anderson, 1983/2016, 5.

2 Adams, 1993, 82.

3 See e.g. Hayek, 1949.

4 Freeden, 1998.

5 Billig, 1995.

6 Wimmer and Schiller, 2002, 302-308.

7 Martins, 1974, 276.

8 Martins, 1974, 276-277.

9 Smith, 1983, 26.

10 Gellner, 1983 and Anderson, 1983/2016.

11 For an overview of the research traditions - historical, sociological and anthropological - on nationalism, see Kramer, 1997 and Thompson and Fevre, 2001.

12 See Wimmer and Schiller, 2002.

13 Spann was Voegelin's supervisor, together with the positivist legal theorist Hans Kelsen - a rather unusual combination.

14 Voegelin, 1922a/2003, 22.

15 Duhem, 1906/2007, 114-15, 122-23; Voegelin, 1922a/2003, 22; 1922b/2003, 46; 1930/2003, 443.

16 Duhem, 1906/2007, 148f.

17 Voegelin, 1922b/2003, 29-30.

18 Voegelin, 1922b/2003, 48.

19 Although Talcott Parsons's structural-functionalist (mis)reading of Weber has certainly contributed to the situation that critics of methodological nationalism in social theory deplore.

20 Every undergraduate student of sociology or politics is bound to have come across this sentence at least once: 'a state is a human community that (successfully) claims the monopoly of the legitimate use of physical force within a given territory', in Weber, 1919/1946, 78, emphasis elided.

21 Weber, 1922/1968, 926.

22 Voegelin, 1925/2003, 117.

23 Voegelin, 1930/2003, 450.

24 Voegelin, 1930/2003, 463.

25 Voegelin, 1930/2003, 464.

26 Mannheim, 1929/1954.

27 Voegelin, 1930/2003, 475. 


\section{Pedro T. Magalhães and Laura Sumari}

28 Voegelin, 1934/2001, 1936/1997.

29 Voegelin, 1952, 79.

30 Wimmer and Schiller, 2002.

31 Könönen, 2014a, 18.

32 Anderson, 2019.

33 De Genova, 2005, 57-58; Könönen, 2014a, 18; Sager, 2016.

34 Könönen, 2014b, 188.

35 Amelina and Faist, 2012.

36 Anthias, 2020, 141-146; Anderson, 2019.

37 Amelina and Faist, 2012.

38 Wimmer and Schiller, 2002; Sager, 2016.

39 Könönen, 2012.

40 Hall, 2002, 16.

41 Wimmer and Schiller, 2002, 325.

42 Sayad, 2004, 278.

43 Könönen, 2014a, 18-19; Nissilä, 2016, 60.

44 Könönen, 2014a, 19.

45 Amelina and Faist, 2012.

46 Amelina and Faist, 2012, 1707.

47 Massey, 1993; Kymäläinen, 2006, 206-210.

48 Amelina and Faist, 2012.

49 Anthias, 2008.

50 Amelina and Faist, 2012.

51 See e.g. Marcus, 1995.

52 Nissilä, 2016, 62.

53 Amelina and Faist, 2012.

54 Anthias, 2008.

55 See e.g. Paasi, 2001; Beck, 2006.

56 Anthias, 2008.

57 Massey, 1991, 24-29.

58 Könönen, 2014a, 19.

59 Laine, 2016.

60 Anthias, 2020, 141-144.

61 Anderson, 2019.

62 Anthias, 2008, 8.

63 Anthias, 2008, 9; 2020.

64 Mengiste, 2018.

65 Donna Haraway, 1988.

66 Haraway, 1988, 583, 589.

67 Haraway, 1988, 592.

68 Mengiste, 2018.

69 Treiber, 2013; Mengiste, 2018; Sanchez and Natividad, 2017.

70 Mengiste, 2018, 63.

71 Mengiste, 2018.

72 Voegelin, 1930/2003, 463-464.

73 Anthias, 2008.

74 Shinozaki, 2012.

75 Mohanty, 1991.

76 Shinozaki, 2012.

77 Shinozaki, 2012. 


\section{References}

Adams, Ian. 1993. Political Ideology Today. Manchester: Manchester University Press.

Amelina, Anna, and Thomas Faist. 2012. "De-Naturalizing the National in Research Methodologies: Key Concepts of Transnational Studies in Migration.” Ethnic and Racial Studies 35, no. 10: 1707-24.

Anderson, Benedict. 1983/2016. Imagined Communities: Reflections on the Origin and Spread of Nationalism, 4th ed. London: Verso Books.

Anderson, Bridget. 2019. "New Directions in Migration Studies: Towards Methodological De-Nationalism.” Comparative Migration Studies 7, no. 36. doi: 10.1186/s40878-019-0140-8.

Anthias, Floya. 2008. "Thinking Through the Lens of Translocational Positionality: An Intersectionality Frame for Understanding Identity and Belonging." Translocations 4, no. 1: 5-20.

Anthias, Floya. 2020. Translocational Belongings: Intersectional Dilemmas and Social Inequalities. London: Routledge.

Beck, Ulrich. 2006. The Cosmopolitan Vision. Cambridge: Polity Press.

Billig, Michael. 1995. Banal Nationalism. London: Sage.

De Genova, Nicholas. 2005. Working the Boundaries: Race, Space, and "Illegality" in Mexican Chicago. Durham: Duke University Press.

Duhem, Pierre. 1906/2007. La Théorie Physique: Son Objet, Sa Structure. Paris: Vrin.

Freeden, Michael. 1998. "Is Nationalism a Distinct Ideology?" Political Studies 46, no. 4: 748-65.

Gellner, Ernest. 1983. Nations and Nationalism. Ithaca: Cornell University Press.

Hall, Catherine. 2002. "Introduction." In Civilising Subjects: Metropole and Colony in the English Imagination, 1830-1867, edited by Catherine Hall, 339-50. Cambridge: Polity.

Haraway, Donna. 1988. "Situated Knowledges: The Science Question in Feminism and the Privilege of Partial Perspective." Feminist Studies 14, no. 3: 575-99.

Hayek, Friedrich. 1949. "The Intellectuals and Socialism." The University of Chicago Law Review 16, no. 3: 417-33.

Könönen, Jukka. 2012. "Tutkimuksen Politiikka: Metodologisesta Nationalismista Muuttoliikkeiden Autonomiaan." Liikkeessä Yli Rajojen blog series. Accessed April22,2020.https://liikkeessaylirajojen.fi/tutkimuksen-politiikka-metodologisestanationalismista-muuttoliikkeiden-autonomiaan/

Könönen, Jukka. 2014a. "Tilapäinen Elämä, Joustava Työ: Rajat Maahanmuuton Ja Työvoiman Prekarisaation Mekanismina." PhD diss., University of Eastern Finland.

Könönen, Jukka. 2014b. "Pidätelty Elämä. Rajat Prekaarisuutta Tuottavana Instituutiona." Oikeus 43, no. 2: 171-91.

Kramer, Lloyd. 1997. "Historical Narratives and the Meaning of Nationalism." Journal of the History of Ideas 58, no. 3: 525-45.

Kymäläinen, Päivi. 2006. "Paikan Ajattelun Haasteita.” In Paikka: Eletty, Kuvattu, Kerrottu, edited by Seppo Knuutila, Pekka Laaksonen, and Ulla Piela, 203-17. Jyväskylä: Suomalaisen Kirjallisuuden Seura.

Laine, Jussi. 2016. "The Multiscalar Production of Borders." Geopolitics 21, no. 3 : 465-82.

Mannheim, Karl. 1929/1954. Ideology and Utopia. London: Routledge.

Marcus, George. 1995. "Ethnography in/of the World System: The Emergence of Multisited Ethnography." Annual Review of Anthropology 24: 95-117. 
Martins, Herminio. 1974. "Time and Theory in Sociology." In Approaches to Sociology: An Introduction to Major Trends in British Sociology, edited by J. Rex, 246-94. London: Routledge.

Massey, Doreen. 1991. “A Global Sense of Place.” Marxism Today 38: 24-29.

Massey, Doreen. 1993. "Power-Geometry and a Progressive Sense of Place." In Mapping the Futures: Local Cultures, Global Change, edited by J. Bird, B. Curtis, T. Putnam, and L. Tickner, 59-69. London: Routledge.

Mengiste, Tekalign Ayalew. 2018. "Refugee Protections from Below: Smuggling in the Eritrea-Ethiopia Context." The Annals of the American Academy of Political and Social Science 676, no. 1: 57-76.

Mohanty, Chandra. 1991. "Under Western Eyes: Feminist Scholarship and Colonial Discourses." In Third World Women and the Politics of Feminism, edited by Chandra Mohanty, Ann Russo, and Lourdes Torres, 51-80. Bloomington: Indiana University Press.

Nissilä, Hanna-Leena. 2016. “"Sanassa Maahanmuuttaja On Vähän Kitkerä Jälkimaku”: Kirjallisen Elämän Ylirajaistuminen 2000-luvun Alun Suomessa.” PhD diss., University of Oulu.

Paasi, Anssi. 2001. "Europe as a Social Process and Discourse: Considerations of Place, Boundaries and Identity." European Urban and Regional Studies 8, no. 1: 7-28.

Sager, Alexander. 2016. "Methodological Nationalism, Migration and Political Theory." Political Studies 64, no. 1: 42-59.

Sanchez, Gabriella, and Nicholas Natividad. 2017. "Reframing Migrant Smuggling as a form of Knowledge: A View from the U.S.-Mexico Border." In Border Politics: Defining Spaces of Governance and Forms of Transgressions, edited by Cengiz Günay, and Nina Witjes, 67-83. Cham: Springer.

Sayad, Abdelmalek. 2004. The Suffering of the Immigrant. Cambridge: Polity.

Shinozaki, Kyoko. 2012. "Transnational Dynamics in Researching Migrants: Selfreflexivity and Boundary-drawing in Fieldwork." Ethnic and Racial Studies 35, no. 10: $1810-27$.

Smith, Anthony. 1983. "Nationalism and Classical Social Theory." British Journal of Sociology 34, no. 1: 19-38.

Thompson, Andrew, and Ralph Fevre. 2001. "The National Question: Sociological Reflections on Nation and Nationalism." Nations and Nationalism 7, no. 3: 297-315.

Treiber, Magnus. 2013. "Lessons for Life. Two Migratory Portraits from Eritrea." In Long Journeys: Lives and Voices of African Migrants on the Road, edited by Alessandro Triulzi, and Robert McKenzie, 187-212. Leiden: Brill.

Voegelin, Eric. 1922a. "Interaction and Spiritual Community." In The Collected Works of Eric Voegelin, vol. 32, 19-140. Columbia: University of Missouri Press.

Voegelin, Eric. 1922b. "The Social Determination of Sociological Knowledge: A Sociological Examination." In The Collected Works of Eric Voegelin, vol. 7, 27-48. Columbia: University of Missouri Press.

Voegelin, Eric. 1925/2003. “On Max Weber.” In The Collected Works of Eric Voegelin, vol. 7, 100-17. Columbia: University of Missouri Press.

Voegelin, Eric. 1930/2003. "National Types of Mind and the Limits to Interstate Relations." In The Collected Works of Eric Voegelin, vol. 32, 430-82. Columbia: University of Missouri Press.

Voegelin, Eric. 1934/2001. "Drafting a Constitution for Austria." In The Collected Works of Eric Voegelin, vol. 9, 23-7. Columbia: University of Missouri Press.

Voegelin, Eric. 1936/1997. Der Autoritäre Staat. Vienna: Springer. 
Voegelin, Eric. 1952. The New Science of Politics. Chicago: University of Chicago Press.

Weber, Max. 1919/1946. "Politics as a Vocation." In From Max Weber: Essays in Sociology, edited by Hans Heinrich Gerth, and Charles Wright Mills, 77-128. New York: Oxford University Press.

Weber, Max. 1922/1968. Economy and Society. Berkeley: University of California Press.

Wimmer, Andreas, and Nina Glick Schiller. 2002. "Methodological Nationalism and Beyond: Nation-State Building, Migration and the Social Sciences." Global Networks 2, no. 4: 301-34. 